\title{
A cross-sectional study on COVID19 mortality among people below 30 years of age in Tamilnadu-2020
}

\author{
V. Vijay Anand ${ }^{\text {a }}$, G. Arunkumar Yogaraj ${ }^{\text {a, }}$, S. Priya ${ }^{\text {a }}$, P. Priya Raj ${ }^{\text {b }}$, C. Brinda Priyadharshini ${ }^{\text {a }}$, \\ P.N. Sridevi ${ }^{\text {a }}$ \\ ${ }^{\text {a }}$ Institute of Community Medicine, Madurai Medical College, India \\ ${ }^{\mathrm{b}}$ DDHS, Chengalpattu, Tamilnadu, India
}

\section{A R T I C L E I N F O}

\section{Keywords:}

*COVID19 deaths

Young age

Mann whitney $U$ test

Public health

Co-morbidity

\begin{abstract}
A B S T R A C T
Introduction: The COVID19 pandemic has turned out to be one of the public health* burdens in 2020. The fear of deaths due to COVID19 has surmounted even in developed countries and hasn't spared young age. This study aims in assessing the mortality due to COVID19 among patients below 30years of age in TamilNadu.

Methods: The data was collected from a publicly available secondary data source(www.stopcorona.tn.gov.in) which is an official COVID19 state dashboard. Details of the young COVID19 deaths* under 30yrs of age, their gender, symptoms, Co-morbidities, date of symptoms, date of admission, and death were collected till October 2020. A total of 158 deaths were included in the analysis. Fischer exact test and Mann Whitney $U$ test* were used and p-value $<0.05$ was considered significant.

Results: Among the 158 COVID19 deaths under 30 years of age, the median age affected was 25 years(IQR-7) and $70.3 \%(\mathrm{n}-111)$ had at least one co-morbidity*. The median time interval between symptom onset and hospital admission was 3 days (IQR-3) and between admission and death was 4 days(IQR-7).There was a significant association of myocarditis, refractory seizures, Central nervous system involvement as the cause of death in the age group $0-15 y e a r s$, compared with $16-30$ years $(\mathrm{p}<0.05)$. The majority of deaths occurred with a late presentation, also patients with higher age were admitted after 2 days of symptoms and the results were statistically significant $(\mathrm{p}<0.05)$.

Conclusion: Understanding the age-dependent risk gradient and their trend of this new virus at young age* is essential for public health planning and prevent future deaths, future research gateways.
\end{abstract}

\section{Introduction}

In December 2019, an unusual surge of pneumonia cases led to the discovery of a new strain of Coronavirus (named as 2019-nCov/SARSCOV2) in Wuhan, the capital of Hubei province in China. The disease was named novel-Coronavirus disease-19 (COVID-19). ${ }^{1}$ Cases spread across other Chinese provinces and internationally, forming several epicenters resulting in a global outbreak. On January 30, 2020, WHO declared COVID -19 as a Public Health Emergency of International Concern (PHEIC). COVID-19 with its human-human spread, droplet transmission, as well as through global transport hubs with a huge number of inbound and outbound passengers resulted in a major disastrous pandemic. ${ }^{2}$ On January 27, 2020, India reported its first case in Kerala, a 20-year-old female who traveled from Wuhan city, due to the COVID-19 outbreak situation. ${ }^{3}$ Later, despite precautionary measures, due to population migration, several clusters were formed and the disease spread nationwide. Daily several new COVID19 cases and deaths were reported with mounting pressure in the health care system. India, as of October 31,2020, roughly 1.2 lakh deaths had occurred among the $81,83,394$ COVID19 positive cases. TamilNadu reported 11, 122 deaths among the 7,24,522 cases. ${ }^{4}$ Fig. 1 shows the gradual rise in the number of COVID19 cases in Tamil Nadu from the 12th of April and the weekly total COVID19 deaths. The peak was attained in the 15th -18 th week and then the infection rate and deaths slowed a decline from the 25th week.

In early 2020, the focus was mainly on elderly friable individuals and the risk of dying of non-elderly individuals was small. In stark contrast, as months passed, many new stories started to emerge focussing on the demise of young people causing panic and horror which are largely reverberated stories. ${ }^{5}$ In comparison to 14 European countries and 13-

\footnotetext{
* Corresponding author.

E-mail address: arunvino.yoga@gmail.com (G. Arunkumar Yogaraj).
} 
United States locations which were the epicenters of the COVID19 pandemic, the overall risk of non-elderly individuals $(<60$ years) in India and Mexico was only 10 fold lower. ${ }^{6}$ Joan.P.A.Ioannidis et al. mentioned that until May 21, the proportion of COVID19 deaths for less than 40 years of age was $14.4 \%(n=3435)$. The absolute risk of COVID19 deaths of the non-elderly population was 5 per million in India. ${ }^{6}$

Now, it's been nearly a year since the SARS-COV2 virus emerged. Data suggested that young age death also contributed a significant ratio. They are the future workforce of the country. Losing this fraction of the population at any cause will have a greater impact on the Nation's economy [Gross National Product(GNP) and Gross Domestic Product (GDP) ]. Only a few studies have described COVID19 deaths in younger age groups globally.

A descriptive analysis is essential for understanding the trends and the most common factors involved in the deaths of this new disease. Such details will form the base of future analytical research, extrapolating the risk factors, treating these individuals, formulating new guidelines, and in the planning of the health system for a strategic approach towards the disease.

\section{Methodology}

The data was collected from the Government of Tamil Nadu COVID19 daily media bulletin release (www.stopcorona.tn.gov.in/) which is a secondary data source and publicly available in the official COVID19 dashboard of the state. Information on the COVID19 deaths such as each patient's sociodemographic details, date of Rt-PCR positivity, date of admission at the isolation facility, date and cause of death, symptoms and its onset and co-morbidities were collected from March to October 2020.

A total of 11122 COVID19 deaths had occurred in Tamil Nadu till 31, October 2020. Full details were not available for 470 deaths. A total of 10652 COVID19 Death summaries were screened and among them, details of 158 COVID19 deaths under 30 years of age with all the information were included for analysis.

We expressed the categorical variables as frequency, percentage with $95 \%$ confidence interval (C.I), the continuous variable as Mean, Median, Standard deviation, Maximum and Minimum values, and Interquartile range (IQR). For further analysis, the Chi-squared test $\left(\chi^{2}\right)$ or the Fischer exact test were used for categorical variables and Independent sample $t$ test/Mann-Whitney $U$ test for continuous variables with a p-value $<0.005$ as significant. SPSS software version 21.0 (IBM) was used.

\section{Results}

Table 1: Nearly $85 \%(\mathrm{n}=135,95 \%$ C.I $=78.96 \%-90.54 \%)$ of the deceased belonged to the age group $16-30$ years and $55.7 \%$ of the deceased were male $(\mathrm{n}=88,95 \% \mathrm{CI}=47.59 \%-63.59 \%)$. A total of $\mathrm{n}=$ $111(70.25 \%$, 95\% C.I $=62.47 \%-77.25 \%)$ had one or more comorbidities and $\mathrm{n}=43(27.22 \%, 95 \%$ C.I $=20.45 \%-34.86 \%)$ belonged to Chennai and Chengalpattu districts. Nearly $94 \%$ ( $n=148$, 95\% C.I: $88.67 \%-96.92 \%$ ) had died due to respiratory cause, among them majority had Bronchopneumonia (91\%), ARDS and respiratory failure (44\%). Cardiovascular cause accounts for about $22.2 \%(n=35$, 95\% C.I: $15.94 \%-29.44 \%$ ) with cardio-respiratory arrest (16.5\%) being common. Other than the respiratory and cardiac causes, Sepsis and Coagulopathy/Thromboembolic cause amounts to nearly $14.6 \%$ ( $\mathrm{n}=$ 23, 95\% C.I:9.46\%-21.04\%) and 7.6\% $(\mathrm{n}=12$, 95\% C.I:3.99\%-12.89\%) respectively. Renal cause (with Acute kidney injury $\mathrm{n}=8,5.1 \%$ ), metabolic causes and Central nervous system involvement (with Refractory seizures $n=4,2.5 \%)$ all amounts to $6.3 \%(n=10,95 \%$ C.I: 3.08-11.33) of total COVID19 deaths under 30years of age. Renal disorder $24.3 \%$ ( $n=27,95 \%$ C.I: $16.68 \%-33.38 \%$ ) was the most common comorbidity associated COVID19 deaths under 30 years of age among which $19.8 \%$ ( $n=22$, 95\% C.I: $12.86 \%-28.46 \%$ ) had Chronic Kidney Disease. Central nervous system disorder $22.5 \%(\mathrm{n}=25,95 \%$ C.I: 15.14 $\%-31.43 \%$ ) was the second most common comorbidity with seizure disorder contributing about $11.7 \%(\mathrm{n}=13$, 95\% C.I: $6.39-19.19)$. Diabetes and Hypertension accounts for about $18 \%$ and $13.5 \%$ respectively. 15.3\% had Haematological/coagulation disorder with anemia (n $=7,6.3 \%$, 95\% C.I: $2.57-12.56$ ) being most common among them. Leukemia ( $n=6,5.4 \%, 95 \%$ C.I: $2.01-11.39$ ) was the common among the cancers $(\mathrm{n}=13,11.7 \%$, 95\% C.I: $6.39 \%-19.19 \%)$ as co-morbidity.

Table 2: The median age among, COVID19 deaths below 30 years of age was 25 years (IQR-7), with not much difference in the gender [Males- 26yrs (IQR-6) and Females- 25yrs (IQR-9.5)]. The median time interval between symptom onset and hospital admission was 3 days (IQR-3) and was slightly less when compared with the median time interval between admission and death which, 4 days (IQR-7).

Table 3: A Fisher-exact test showed a statistically significant association of myocarditis, refractory seizures/Status epileptics, Central nervous system involvement as the cause of death in COVID19 deaths in age group 0-15 years as compared with $16-30$ years (p-value $<0.05$ ). The other categorical variables were not significant with the age group. Similarly, the Fischer-exact test showed $55.56 \%(n=5)$ of the COVID19 deaths having respiratory disorder as co-morbidity belonged to the of

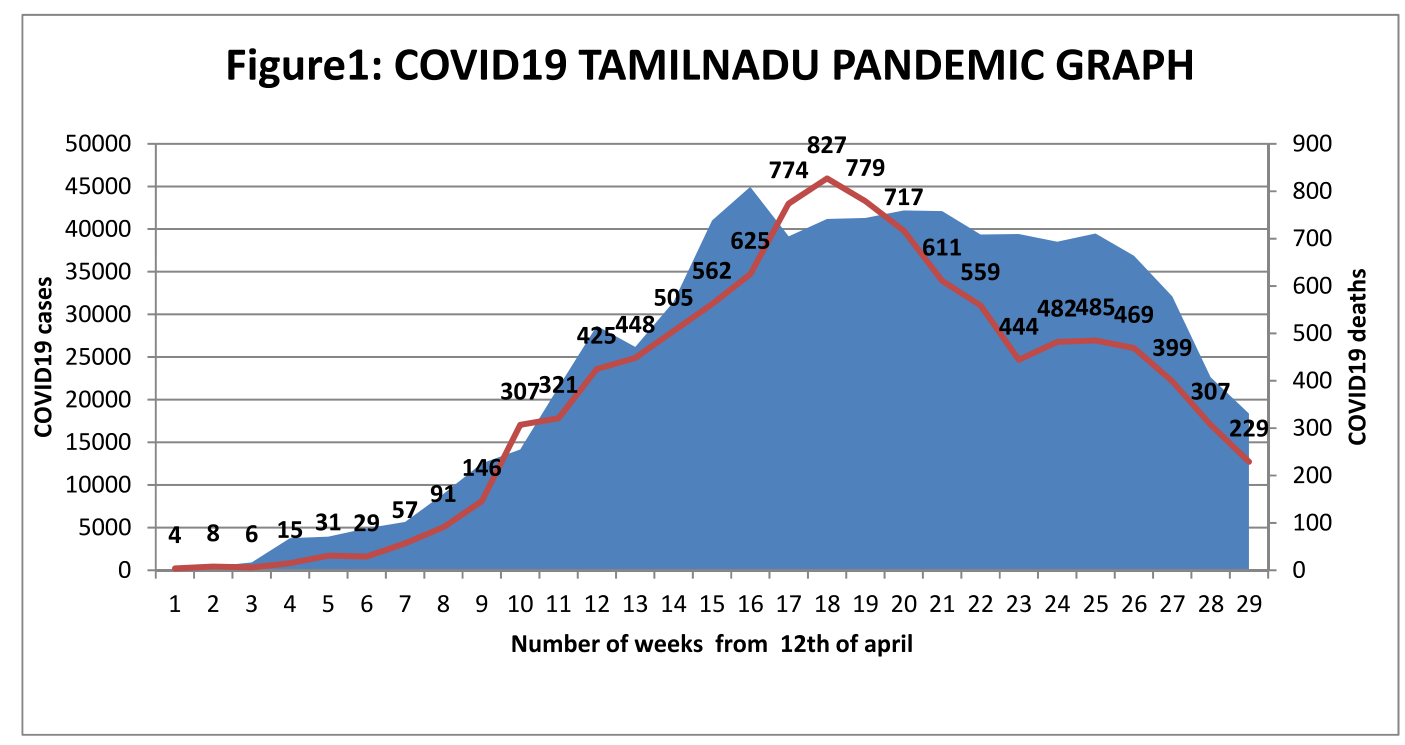

Fig. 1. Covid19 tamilnadu pandemic graph. 
Table 1

Descriptive analysis.

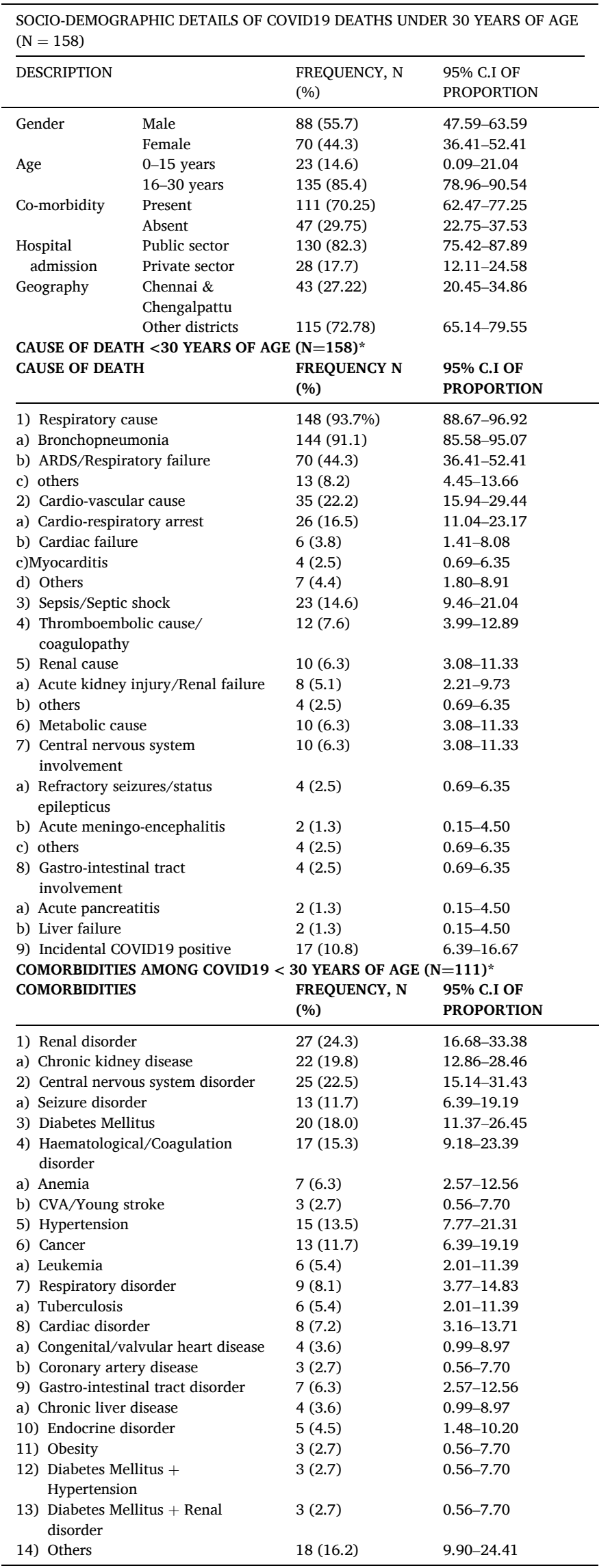

Table 2

Age and hospital-specific time intervals.

\begin{tabular}{lll}
\hline Details & Median & IQR \\
\hline $\begin{array}{l}\text { Age }<30 \text { Years }(\mathrm{n}=158) \\
\text { The time interval between } \\
\text { symptoms onset and hospital }\end{array}$ & 25 yrs & 7 \\
$\begin{array}{l}\text { admission. }(\mathrm{n}=35) \\
\text { The time interval between }\end{array}$ & 3 days & 3 \\
$\begin{array}{l}\text { Hospital admission and death. } \\
(\mathrm{n}=154)\end{array}$ & 4 days & 7 \\
\hline
\end{tabular}

Table 3

Inferential analysis.

\begin{tabular}{|c|c|c|}
\hline \multicolumn{3}{|c|}{ Cause of death and age groups $(n=158)$} \\
\hline & Myocarditis (n = 4) & $\begin{array}{l}\text { p-value }{ }^{\text {a }} \text { (Fischer- } \\
\text { exact) }\end{array}$ \\
\hline $\begin{array}{l}\text { Age group } 0-15 \text { years } \\
\qquad(\mathrm{n}=23)\end{array}$ & $3(75 \%)$ & 0.010 (sig) \\
\hline \multirow{2}{*}{$\begin{array}{l}\text { Age group } 16-30 \\
\text { years }(n=135)\end{array}$} & $1(25 \%)$ & \\
\hline & $\begin{array}{l}\text { Refractory seizures/Status } \\
\text { epileptics }(n=4)\end{array}$ & $\begin{array}{l}\text { p-value }{ }^{\text {a }} \\
\text { (Fischer-exact) }^{\text {Fischen }}\end{array}$ \\
\hline $\begin{array}{l}\text { Age group } 0-15 \text { years } \\
\quad(n=23)\end{array}$ & $3(75 \%)$ & 0.010 (sig) \\
\hline \multirow{3}{*}{$\begin{array}{l}\text { Age group } 16-30 \\
\text { years }(\mathrm{n}=135)\end{array}$} & $1(25 \%)$ & \\
\hline & Central Nervous System & p-value ${ }^{a}$ \\
\hline & Involvement $(n=10)$ & (Fischer-exact) \\
\hline $\begin{array}{l}\text { Age group } 0-15 \text { years } \\
\quad(n=23)\end{array}$ & $6(60 \%)$ & 0.0007 (sig) \\
\hline $\begin{array}{l}\text { Age group 16-30 } \\
\text { years }(n=135)\end{array}$ & $4(40 \%)$ & \\
\hline \multicolumn{3}{|c|}{ Co-morbidities and Socio-demographic details $(n=111)$} \\
\hline & Respiratory disorder $(n=9)$ & $\begin{array}{l}\text { p-value }{ }^{a} \\
\text { (Fischer-exact) }^{\text {a }}\end{array}$ \\
\hline $\begin{array}{l}\text { Age group } 0-15 \text { years } \\
\quad(n=18)\end{array}$ & $4(44.44 \%)$ & 0.037 (sig) \\
\hline \multirow{2}{*}{$\begin{array}{l}\text { Age group } 16-30 \\
\text { years }(n=93)\end{array}$} & $5(55.56 \%)$ & \\
\hline & $\begin{array}{l}\text { Endocrine disorder Excluding } \\
\text { Diabetes Mellitus }(n=5)\end{array}$ & $\begin{array}{l}\text { p-value } \\
\text { (Fischer-exact) }^{\mathrm{a}}\end{array}$ \\
\hline Public sector $(\mathrm{n}=91)$ & $2(40 \%)$ & 0.040 (sig) \\
\hline $\begin{array}{l}\text { Private sector }(\mathrm{n}= \\
\text { 20) }\end{array}$ & $3(60 \%)$ & \\
\hline
\end{tabular}

age group 16-30 years when compared with age group 0-15 years and the p-value was statistically significant $(<0.05)$. Also, $60 \%(n=3)$ of the COVID19 deaths under 30 years with the endocrine disorder excluding Diabetes mellitus was treated in private sector when compared with the public sector and the p-value was significant $(<0.05)$. The other comorbidities were not significant with other variables.

Table 4: A non-parametric test (Mann-Whitney $U$ test) indicated that age was greater for males $(n=88$, mean rank 87.32) than females $(n=$ 70 , mean rank 69.67) and the results were statistically significant $(\mathrm{U}=$ 2392, p < 0.05). Similarly, among COVID19 deaths under 30 years of age, patients with higher age were admitted after 2 days of symptoms onset ( $n=24$, larger mean rank 20.60) as compared with those admitted within 2 days of symptom onset $(n=11$, mean rank 12.32) and the results were statistically significant $(U=69.50, p<0.05)$. Also, a MannWhitney $U$ test indicated that for COVID19 deaths under 30 years of age private sector $(n=27)$ had a larger mean rank (102.0) for the time interval between admission and death than the public sector $(n=127)$ with a mean rank of 72.29. The difference was statistically significant (U $=1.503, \mathrm{p}<0.05$ ).

\section{Discussion}

As of 31 , October 2020 among the 7,24,522 COVID19 positive cases, 
Table 4

Inferential analysis for continuous variables (Age, Time interval between symptom onset And admission, Time interval between admission and death).

\begin{tabular}{|c|c|c|c|c|c|c|}
\hline Variable & $\begin{array}{l}\text { Grouped } \\
\text { Variable }\end{array}$ & $\mathrm{n}$ & $\begin{array}{l}\text { Mean } \\
\text { Rank }\end{array}$ & $\begin{array}{l}\text { Sum of } \\
\text { ranks }\end{array}$ & $\begin{array}{l}\text { Mann } \\
\text { Whitney- } \\
\text { U }\end{array}$ & $\begin{array}{l}\mathrm{p}- \\
\text { value }^{\mathrm{a}}\end{array}$ \\
\hline \multirow{2}{*}{$\begin{array}{l}\text { Age } \\
\qquad(n=158)\end{array}$} & Male & 88 & 87.32 & 7684.00 & 2392 & \multirow{2}{*}{$\begin{array}{l}0.016 \\
\text { (sig) }\end{array}$} \\
\hline & Female & 70 & 69.67 & 4877.00 & & \\
\hline \multirow[t]{2}{*}{ Age $(n=35)$} & $\begin{array}{l}\text { Time } \\
\text { interval } \\
\text { between } \\
\text { Symptom } \\
\text { onset and } \\
\text { Admission } \\
\leq 2 \text { days }\end{array}$ & 11 & 12.32 & 135.50 & 69.50 & $\begin{array}{l}0.025 \\
\text { (sig) }\end{array}$ \\
\hline & $\begin{array}{l}\text { Time } \\
\text { interval } \\
\text { between } \\
\text { Symptom } \\
\text { onset and } \\
\text { Admission } \\
>2 \text { days }\end{array}$ & 24 & 20.60 & 494.50 & & \\
\hline $\begin{array}{l}\text { Time } \\
\text { interval } \\
\text { Between }\end{array}$ & $\begin{array}{l}\text { Public } \\
\text { sector } \\
\text { admission }\end{array}$ & 127 & 72.29 & 9181.00 & 1.053 & $\begin{array}{l}0.002 \\
(\mathrm{sig})\end{array}$ \\
\hline $\begin{array}{l}\text { admission } \\
\text { and death } \\
(n=154)\end{array}$ & $\begin{array}{l}\text { Private } \\
\text { sector } \\
\text { admission }\end{array}$ & 27 & 102.00 & 2754.00 & & \\
\hline
\end{tabular}

${ }^{\text {a }}$ p-value of $<0.05$ is considered to be significant.

a total of 11,122 deaths have been reported in Tamilnadu(7) \{Case fatality rate $=1.54 \%$, Disease-specific mortality rate $=15.42$ per 1 lakh population, samples tested $=9,95,6210$, Positivity rate $-7.27 \%$. Among these, 158 COVID19 deaths $(1.42 \%, 95 \% \mathrm{CI}=1.21-1.66)$ have occurred under 30 years of age which is about $1.42 \%$ (95\% CI: $1.21-1.66)$. Though this may seem to be a small proportion, analyzing the trends in the common co-morbidities, causes of death, delay in presentation to hospital is highly important in understanding the pattern of the deaths of this new disease. This may prove beneficial in predicting the young age mortality, who present to the hospital with the most common factors. Special focus can be given to treating such patients and prevent their death.

In this study, the median age of COVID19 deaths in young age was 25 years (IQR-7) with no much difference of median age in males and females. A study done by Shahir Asfahan et al. showed that the odds ratio (OR) of dying from COVID19 for every 10-year increase in age was 3.4 and for the presence of any of the comorbidities was 10.3. ${ }^{11}$ Stockman et al. reported that the clinical outcome of the coronavirus was more favorable in children below 12 years of age than in other age groups. ${ }^{17}$ In the MERS-CoV epidemic, only two pediatric age deaths were reported and both of them had comorbidities (infantile nephrotic syndrome and cystic fibrosis). ${ }^{18-20}$ On the contrary, there is no clear evidence for a young age sparing pattern of COVID19. In the largest pediatric study in China, which analyzed 2143 children with COVID19 infection, $5.8 \%$ of children showed severe and critical illness. ${ }^{21}$

As per the 2011 census, Chennai including Chengalpettu had a population of $46,81,087$ which is roughly $7 \%$ of the total population of Tamil Nadu. ${ }^{8}$ In this pandemic, 2,43,570 of them turned out to be COVID19 positive which is $33.61 \%$ of total COVID19 cases of Tamilnadu and around $27.22 \%(n=43,95 \%$ C.I: $20.45-34.86)$ of young age COVID19 deaths had occurred in this region. ${ }^{7}$

Generally, each case has a direct cause (primary cause) and one or more underlying cause (secondary cause) of death. The differentiation was not mentioned in the data source and so causes of death may overlap. Similarly, comorbidities also may overlap and the most common comorbidities under each system are mentioned in Table 1. Edwin sam Asirvatham et al. in their study also described overlapping of comorbidities in their study on COVID19 deaths in Tamil Nadu. ${ }^{9}$

Apart from respiratory disorders, Cardiovascular $(22.2 \%, \mathrm{n}=35)$, sepsis $(14.6 \%, \mathrm{n}=23)$, coagulopathy $(7.6 \%, \mathrm{n}=12)$, renal failure $(5.1 \%, \mathrm{n}=8)$ significantly contributed to the cause of death under 30 years. This finding recommends to reduce COVID-19 mortality at a young age, the treatment of respiratory conditions needs to be combined with appropriate management of associated conditions. Comprehensive strategies to prevent and reduce the effects of non-respiratory complications are in need for the hour. A similar study by Luigi Palmeri et al. done in Italy showed a higher rate of non-respiratory complications in younger individuals than older patients, Acute renal failure $(30.0 \% \mathrm{Vs}$ $20.6 \%)$, Acute Cardiac injury (13.5\% Vs $10.3 \%$ ), and superinfections (30.9\% Vs $9.8 \%)$ resulting in death. ${ }^{10}$ Also a multi-system inflammatory syndrome is reported among children by WHO. ${ }^{12}$ The report describes that, clusters of children and adolescents requiring hospital admission with a multisystem inflammatory condition, and some features similar to Kawasaki disease and toxic shock syndrome, in continents like Europe and North America ${ }^{13-15}$

Among the 158 COVID19 young age deaths, $70.3 \%(n=111,95 \% \mathrm{C}$. I: $62.47-77.25)$ had at least one co-morbidity and $29.7 \%(n=47,95 \%$ C. I: 22.75-37.53) died without any known co-morbidities. Nearly $60 \%$ (N $=111, \mathrm{n}=66,95 \%$ C.I: $49.72-68.68)$ of young age mortality had one comorbidity, and $40.54 \%(\mathrm{~N}=111, \mathrm{n}=45,95 \%$ C.I: $31.32-50.28)$ had one or more comorbidities. A study done by Luigi Palmieri et al. showed that $10.9 \%$ of the younger patients who died of COVID19 had no associated comorbidities in Italy. ${ }^{10}$

In this study, the median time interval between symptom onset and admission was 3 days and the time interval between admission and death was 4 days. Luigi Palmieri et al. results showed their median time intervals were 5 days and 9 days respectively, which is comparatively higher in Italy. ${ }^{10}$ Edwin sam Asirvatham et al. in their study on COVID19 deaths in Tamil Nadu till July 2020, has stated that the median time intervals were 4 days for both the factors which are nearly similar to our results analyzed till October 2020 for deaths in the young age group. ${ }^{3}$

Among the morbid COVID19 patients under 30 years of age who sought hospital care, $68.57 \%(\mathrm{~N}=35, \mathrm{n}=24,95 \% \mathrm{CI}$ : 50.71-83.15) were admitted after 2 days of symptom onset and only $31.43 \%(\mathrm{~N}=35$, $\mathrm{n}=11$, 95\% CI: $16.85-49.29$ ) were admitted within first 2 days of symptom onset. This trend indicates that the majority of deaths occurred with a late presentation and this finding is a matter of concern to save the life of young COVID19 patients. Also a Mann Whitney $U$ test ( $\mathrm{U}=$ 69.50, $\mathrm{p}<0.05$ ) indicated that patients with higher age (within the under 30 years) were admitted after 2 days of symptoms onset $(n=24$, larger mean rank 20.60) as compared with those who were admitted within 2 days of symptom onset $(\mathrm{n}=11$, mean rank 12.32).

Also, $27.92 \%$ of deaths ( $\mathrm{N}=154, \mathrm{n}=43$, 95\% C.I: $21.0-35.71$ ) of young age occurred within 1 day of admission. This might be due to delayed presentation, however, in our analysis, the results were not significant. Further research is needed with a large sample size to find the association between COVID19 mortality and delayed presentation to the hospital.

Seung-Ji Kang et al. in their study have mentioned that the increasing mortality rate with age is not a specific finding for COVID-19. However, many researchers, scientists, and media have focussed attention on elderly age as a risk factor for mortality in COVID-19. This might be due to the relative surge of infected patients and deaths within a very short period. Further studies are needed to completely understand the epidemiology of this disease. ${ }^{16}$ Joan. P.A. Ioannidis et al. have encouraged the public health authorities to report systematic data on each of the major comorbidities according to age strata. ${ }^{6}$ We believe this article would contribute the data for further analytical research on risk factors of young age COVID19 deaths.

\section{Conclusion}

With such a rapid global spread of the coronavirus (COVID19) mutations, antigenic shift and drift are very common and can turn into favorable or unfavorable outcome at any moment. Investigating the 
susceptibility to infection in the general public is highly impractical because many COVID19 cases are asymptomatic, or mildly symptomatic and some even don't know they had the disease. So, understanding the age-dependent risk gradient and their trend of this new virus in young is also essential to understand the disease and act accordingly. Young people are more prone to COVID19 infections due to high exposure certainty when compared with the elderly. Adequate COVID-19 testing, management of the underlying co-morbidity effectively, comprehensive treatment plans, diverting needed health resources towards young COVID 19 patients will help to save these lives. Also, draconian measures of personal and public hygiene with good infection prevention control activities are ultimately essential in the drastic reduction of deaths due to COVID19.

\section{Limitation}

Full death details were not available for 474 deaths (444 deaths which were notified on July 22, 2020 after the report of Death reconciliation Committee in Greater Chennai Corporation and details of first 30 deaths). There was no comparison group of the non-morbid COVID19 individuals of the same age group for analysis.

\section{Financial interest}

None.

Funding

This research did not receive any specific grant from funding agencies in the public, commercial or non-profit sectors.

\section{Data integrity}

Datas were extracted from a publicly available open source. (www. stopcorona.tn.gov.in)- a government of Tamilnadu COVID19 dashboard.

\section{Submission declaration}

This work is not published previously or considered for publication. Publication is approved by all authors and by responsible authorities where work has been carried out. If accepted it will not be published elsewhere in the same form without written consent of copyright holder.

\section{Declaration of competing interest}

None.

\section{References}

1 Wu Y-C, Chen C-S, Chan Y-J. The outbreak of COVID-19: an overview. J Chin Med Assoc. 2020 Mar;83(3):217-220.

2 Wu JT. Nowcasting and Forecasting the Potential Domestic and International Spread of the 2019-nCoV Outbreak Originating in Wuhan, China: A Modelling Study :vol. 9.

3 Andrews M, Areekal B, Rajesh K, et al. First confirmed case of COVID-19 infection in India: a case report. Indian J Med Res. 2020;151(5):490.

4 Daily bulletin - StopCoronaTN [internet]. [cited 2020 nov 15]. Available from: https ://stopcorona.tn.gov.in/daily-bulletin/.

5 Hundreds of young Americans have now been killed by the coronavirus, data shows. Washington Post [Internet] [cited 2020 Dec 20]; Available from: https://www.wash ingtonpost.com/health/2020/04/08/young-people-coronavirus-deaths/.

6 Ioannidis JPA, Axfors C, Contopoulos-Ioannidis DG. Population-level COVID-19 mortality risk for non-elderly individuals overall and for non-elderly individuals without underlying diseases in pandemic epicenters. Environ Res. 2020 Sep;188: 109890.

7 Media-Bulletin-31-10-20-COVID-19-6-PM.pdf [internet]. [cited 2020 nov 20]. Available from: https://stopcorona.tn.gov.in/wp-content/uploads/2020/03/Media -Bulletin-31-10-20-COVID-19-6-PM.pdf.

8 Tamil Nadu_PPT_2011-BOOK FINAL.pdf [internet]. [cited 2020 dec 10]. Available from: https://censusindia.gov.in/2011-prov-results/data_files/tamilnadu/3.Tamil\% 20Nadu_PPT_2011-BOOK\%20FINAL.pdf.

9 Asirvatham ES, Sarman CJ, Saravanamurthy SP, Mahalingam P, Maduraipandian S, Lakshmanan J. Who is dying from COVID-19 and when? An Analysis of fatalities in Tamil Nadu, India. Clin. Epidemiol. Global Health. 2020 Oct. S2213398420302189.

10 Palmieri L, Vanacore N, Donfrancesco C, et al. Clinical characteristics of hospitalized individuals dying with COVID-19 by age group in Italy. In: Newman A, ed. The Journals of Gerontology: Series A. vol. 75. 2020 Sep 16:1796-1800, 9.

11 Asfahan S, Deokar K, Dutt N, Niwas R, Jain P, Agarwal M. Extrapolation of mortality in COVID-19: exploring the role of age, sex, co-morbidities and health-care related occupation. Monaldi Arch Chest Dis [Internet]. 2020 May 21 [cited 2020 Dec 7];90 (2). Available from:: https://monaldi-archives.org/index.php/macd/article/view/ 1325.

12 Multisystem inflammatory syndrome in children and adolescents temporally related to COVID-19 [Internet]. [cited 2020 Nov 29]. Available from: https://www.who.int /news-room/commentaries/detail/multisystem-inflammatory-syndrome-in-childr en-and-adolescents-with-covid-19.

13 DeBiasi RL, Song X, Delaney M, et al. Severe COVID-19 in children and young adults in the Washington, DC metropolitan region. J Pediatr. 2020.

14 Riphagen S, Gomez X, Gonzalez-Martinez C, Wilkinson N, Theocharis P. Hyperinflammatory shock in children during COVID-19 pandemic. Lancet. 2020 May 23;395(10237):1607-1608.

15 Jones VG, Mills M, Suarez D, et al. COVID-19 and Kawasaki disease: novel virus and novel case. Hosp Pediatr. 2020 Jun;10(6):537-540.

16 Kang S-J, Jung SI. Age-Related morbidity and mortality among patients with COVID19. Infect Chemother. 2020;52(2):154.

17 Stockman LJ, Massoudi MS, Helfand R, et al. Severe Acute respiratory syndrome in children. Pediatr Infect Dis J. 2007 Jan;26(1):68-74.

18 Bartenfeld M, Griese S, Uyeki T, Gerber SI, Peacock G. Middle East respiratory syndrome coronavirus and children: what pediatric health care professionals need to know. Clin Pediatr (Phila). 2017 Feb;56(2):187-189.

19 Thabet F, Chehab M, Bafaqih H, Al Mohaimeed S. Middle East respiratory syndrome coronavirus in children. Saudi Med J. 2015;36:484-486.

20 Memish ZA, Al-Tawfiq JA, Assiri A, et al. Middle East respiratory syndrome coronavirus disease in children. Pediatr Infect Dis J. 2014 Sep;33(9):904-906.

21 Dong Y, Mo X, Hu Y, et al. Epidemiology of COVID-19 among children in China. Pediatrics. 2020 Jun;145(6), e20200702. 